\title{
Antibacterial Properties of Tetrapleura tetraptera pod against some pathogens
}

\author{
Esther Benafegha Enaregha ${ }^{1}$, Sylvester Chibueze Izah $^{2 *}$ and Queen Okiriya ${ }^{1}$ \\ ${ }^{1}$ Department of Biology, Isaac Jasper Boro College of Education, Sagbama, Bayelsa State, Nigeria \\ ${ }^{2}$ Department of Microbiology, Faculty of Science, Bayelsa Medical University, Yenagoa, Bayelsa State, Nigeria
}

\begin{abstract}
This study assessed the antibacterial properties of aqueous, acetone and ethanolic extracts of Tetrapleura tetraptera pod. The samples were bought from Swali market in Yenagoa, Bayelsa state, Nigeria. Water (aqueous), acetone and ethanol were used for the extraction. Agar well diffusion sensitivity testing was employed for the study. Zone of inhibition results for Escherichia coli, Pseudomonas species, Staphylococcus aureus and Proteus species were $8.00 \mathrm{~mm}, 8.00 \mathrm{~mm}, 8.67 \mathrm{~mm}$ and $9.00 \mathrm{~mm}$, respectively for aqueous extracts, $9.33 \mathrm{~mm}, 9.00 \mathrm{~mm}, 11.67 \mathrm{~mm}$ and $10.00 \mathrm{~mm}$, respectively for acetone extracts, and $13.00,11.33 \mathrm{~mm}, 13.33 \mathrm{~mm}$ and $12.00 \mathrm{~mm}$, respectively for ethanolic extracts. Analysis of variance showed that there was no significant difference $(\mathrm{P}>0.05)$ in the zone of inhibition across the various isolates for aqueous, acetone and ethanolic extracts of Tetrapleura tetraptera pod. Based on comparison of the efficacy of the extracts with Ampiclox, the activities were in the statistical order: aqueous < acetone < ethanol < Ampiclox. This indicates that different solvents have varying effects on the antibacterial potentials of the extracts. On the overall, the zone of inhibition exhibited showed that Tetrapleura tetraptera can be used in the development of broad spectrum antibiotics. Hence the need to extract the compounds responsible for antibacterial activities of Tetrapleura tetraptera pods.
\end{abstract}

\section{Introduction}

Drug resistance has been a major challenge associated with the use of antibiotics produced from synthetic sources. This has been a major concern to pharmaceutical microbiologist and herbal medicine scientists. As such, research has focused on suitable alternatives for the synthetic antibiotics and plants have emerged as potential credible replacement [1-18]. Several plants have been widely reported to be effective against various disease including those caused by microorganisms [1-4,9-11]. The distribution of plants that have been reported to possess therapeutic agents depends on its availability and knowledge of the people that use plants in the treatment of diseases.

Till date plants remain a major source of medicine to significant number of global population especially in the developing countries. The use of plants in the treatment of diseases is a common practice in many rural areas. The use of plant is not only limited to the treatment of diseases but also used during child delivery and post natal processes.

Tetrapleura tetraptera which is commonly known as Aridan tree in Southern Nigeria belongs to the Mimosaceae family [12-14]. The fruit of Tetrapleura tetraptera possess a fragrant, characteristically, pungent aromatic odour. This may account for the insecticidal potentials of the plant [15]. The extract of the plant have been reported to be toxic to tadpoles [16] and larvae of Anopheles gambiae [17].

Tetrapleura tetraptera is also used as a food spice in the preparation of cultural delicacies in many rural areas in countries like Ghana and Nigeria. Like most plants, Tetrapleura tetraptera contain valuable phytochemicals and bioactive substances [12-14]. The presence of bioactive substances accounts for the therapeutic potentials of the plants [9].
An ethno-botanical survey and/ or scientific validation of medicinal plants in Nigeria confirmed the use of Tetrapleura tetraptera due to its cytoprotective, piscicidal, antigonadotropic, antimutagenic, antimalarial [18], inflammation, arthritis, hypertension, diabetes, schistosomiasis, epilepsy potentials $[13,15]$. The plant is also known to possess antioxidant, analgesic [15,17], aphrodisiac agent [19], anti-convulsant, anti-ulcerative, neuromuscular, hypotensive, cardio-vascular and hypoglycemic effects and it can be used in the control of intestinal parasites [15,20]. The plant is also used by breastfeeding mothers to prevent postpartum contraction [13]. Microbial infectious are the major cause of infectious diseases. Microbes are generally ubiquitous. Many species of pathogenic microbes have the propensity to cause diseases in plants, animals and humans. Some are normal flora to human and may cause diseases in immuno-compromised individuals. Again, some of the common microbial species can cause nosocomial as well as community acquired infections which can result to severe consequences if untreated.

Previous report on the antimicrobial potentials of Tetrapleura tetraptera focused on the use of petroleum ether, aqueous and ethanolic extracts [21] and cold water and ethanol extracts [22] as the extraction solvent. Hence, this study is focused on assessing the activities of acetone, ethanol and aqueous extract of Tetrapleura tetraptera pod on some bacterial pathogens.

*Correspondence to: Izah SC, Department of Microbiology, Faculty of Science, Bayelsa Medical University, Yenagoa, Bayelsa State, Nigeria, Tel: +2347030192466; E-mail: chivestizah@gmail.com

Key words: antimicrobial, medicinal plants, microorganisms, tetrapleura tetraptera, therapeutics

Received: May 24, 2020; Accepted: July 06, 2021; Published: July 09, 2021 


\section{Materials and methods}

\section{Sample procurement}

Triplicate samples of the Tetrapleura tetraptera used in this study were purchased from Swali market in Yenagoa, the Bayelsa state capital, Nigeria.

\section{Sample preparation}

Triplicate Tetrapleura tetraptera pod were dried at room temperature. Then after, it was macerated using sterile pestle and mortar. The samples were further blended to obtain fine power.

\section{Extraction method}

The extraction was carried out using soaking method previously described by Kigigha, et al. [9], Kigigha, et al. [10,11], Izah, et al. [47] with slight modifications. $5 \mathrm{~g}$ of the blended samples were extracted using $10 \mathrm{ml}$ of the ethanol, aqueous and acetone separately. The sample was soaked for 3 days. Then it was filtered using muslin cloth followed by Whiteman filter paper. The ethanol and acetone was allowed to evaporate before being concentrated.

\section{Source and Preparation of organisms}

The purity of the test bacterial isolates (E.coli, Staphylococcus aureus, Pseudomonas and Proteus species) used in this study were determined following the biochemical test previously described by Cheesbrough [23] and Benson [24].

\section{Antimicrobial screening}

The zone of inhibition exhibited by the various isolates was determined using Agar well diffusion method previously described by Lino and Deogracious [25], Doherty, et al. [26] with slight modification by Agu and Thomas [27], Kigigha, et al. [9], Izah and Aseibai [28]. About $0.4 \mathrm{ml}$ of the test organisms in peptone water that was incubated for 24 hours was spread over a nutrient agar plates. 3 holes of $6 \mathrm{~mm}$ each were made with sterile cork borer. Approximately $2 \mathrm{ml}$ of each of the extracts was dispensed into the agar well separately. Positive control was established i.e. known antibiotics (1\% Ampiclox). All the plates were incubated at room temperature. The zones of inhibition were measured using a metre rule in millimeter after 24 hours of aerobic incubation

\section{Statistical analysis}

Statistical Package for Social Sciences software version was used to carry out the statistical analysis. The data were expressed as Mean \pm standard error. Significant variations was determined using single factorial analysis, and Tukey Honestly Significant Difference test statistics was used to discern the source of observed variation at $\mathrm{p}=0.05$. The chart was plotted using Graph Prism 5.

\section{Results and Discussion}

Table 1 shows the zone of inhibition exhibited by aqueous, acetone and ethanolic extracts of Tetrapleura tetraptera pod. The zone of inhibition for E. coli, Pseudomonas species, Staphylococcus aureus and Proteus species was $8.00 \mathrm{~mm}, 8.00 \mathrm{~mm}, 8.67 \mathrm{~mm}$ and $9.00 \mathrm{~mm}$, respectively for aqueous extracts, $9.33 \mathrm{~mm}, 9.00 \mathrm{~mm}, 11.67 \mathrm{~mm}$ and $10.00 \mathrm{~mm}$, respectively for acetone extracts, and $13.00,11.33 \mathrm{~mm}$, $13.33 \mathrm{~mm}$ and $12.00 \mathrm{~mm}$, respectively for ethanolic extracts. There was no statistical variation $(\mathrm{P}>0.05)$ in the zone of inhibition across the various isolates for each of the extracts.

Figure 1 show the zone of inhibition exhibited by E.coli, Staphylococcus aureus, Pseudomonas and Proteus species when exposed to aqueous, acetone and ethanolic extracts of Tetrapleura tetraptera and Ampiclox. The zone of inhibition of test isolates when exposed to aqueous, acetone and ethanolic extracts of Tetrapleura tetraptera and Ampiclox were $8.00 \mathrm{~mm}, 9.33 \mathrm{~mm}, 13.00 \mathrm{~mm}$ and $24.67 \mathrm{~mm}$, respectively for E.coli, $8.67 \mathrm{~mm}, 11.67 \mathrm{~mm}, 13.33 \mathrm{~mm}$ and $23.33 \mathrm{~mm}$ respectively for Staphylococcus aureus, $8.00 \mathrm{~mm}, 9.00 \mathrm{~mm}$, $11.33 \mathrm{~mm}$ and $23.67 \mathrm{~mm}$ respectively for Pseudomonas species, and $9.00 \mathrm{~mm}, 10.00 \mathrm{~mm}, 12.00 \mathrm{~mm}$ and $21.00 \mathrm{~mm}$, respectively for Proteus species. Statistically, there was a variation $(\mathrm{P}<0.05)$ in the solvents and Ampiclox comparison for each of the test isolates. Furthermore, Tukey Honestly Significance difference test statistics showed that mean value of Ampiclox were the predominant source of the variation observed.

Based on Table 1 and Figure 1, Tetrapleura tetraptera pod extracts has antibacterial activities. This is in consonance with previous works. Ebana, et al. [21] reported that petroleum ether, aqueous and ethanolic extracts of Tetrapleura tetraptera is potent against E. coli, Staphylococcus aureus and Pseudomonas aeruginosa. Achi [22] also reported that cold water and ethanol extracts of Tetrapleura tetraptera are potent against Staphylococcus aureus, E. coli and Pseudomonas aeruginosa. Though, the zone of inhibition exhibited by the test organisms used for this study is different from the ones previously reported by authors. The variation could be due to the differences in concentration of the extracts, solvents used for extracts, physical condition i.e. age of the plant material, strain of the microbial isolates among other factors [3].

Authors have variously reported that the medicinal potentials of plants including Tetrapleura tetraptera is due to the presence of bioactive components $[1,2,9,26]$. Several phytochemicals are found in Tetrapleura tetraptera. Achi [22] reported the presence of tannins and glycoside and absence of include alkaloids, saponin, flavonoids and antraquinones in ethanol and cold water extracts of Tetrapleura tetraptera whole pod. Ebana, et al. [21] reported the presence of reducing compounds (polyphenols, phlobatannins, anthraquinones and hydroxymethyl anthraquinones), alkaloids, flavonoids, glycoside

Table 1. Zones of Inhibition ( $\mathrm{mm}$ ) of aqueous, acetone and ethanolic extracts of Tetrapleura tetraptera fruits against some bacterial isolates

\begin{tabular}{|l|c|c|c|}
\hline \multirow{2}{*}{ Isolates } & \multicolumn{3}{|c|}{ Extracts } \\
\cline { 2 - 4 } & Aqueous & Acetone & Ethanol \\
\hline E.coli & $8.00 \pm 1.00 \mathrm{a}$ & $9.33 \pm 0.58 \mathrm{a}$ & $13.00 \pm 1.00 \mathrm{a}$ \\
\hline Staphylococcus aureus & $8.00 \pm 1.00 \mathrm{a}$ & $9.00 \pm 1.00 \mathrm{a}$ & $11.33 \pm 0.58 \mathrm{a}$ \\
\hline Proteus species & $8.67 \pm 1.53 \mathrm{a}$ & $11.67 \pm 1.53 \mathrm{a}$ & $13.33 \pm 0.58 \mathrm{a}$ \\
\hline
\end{tabular}

Data is expressed as mean \pm Standard Error; The same letters along the column represent sig nificant difference $(\mathrm{P}<0.05)$ according to Tukey Honestly Significant Difference test statistics

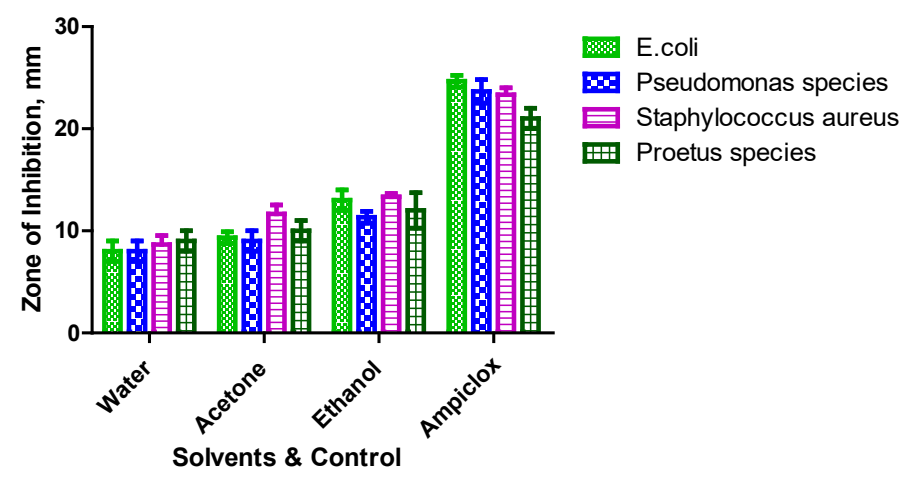

Figure 1. Zones of Inhibition exhibited by E.coli, Staphylococcus aureus, Pseudomonas and Proteus species when exposed to aqueous, acetone and ethanolic extracts of Tetrapleura tetraptera and a positive control (1\% Ampiclox) 
and absence of tannins and saponin in aqueous and ethanolic extracts of Tetrapleura tetraptera. Also, Lin, et al. [29] studied the mechanism of Tetrapleura tetraptera root extract against Escherichia coli and Staphylococcus aureus and reported that plant can disrupt the respiratory metabolism by inhibiting the organism through the Embden-Meyerhof-Parnas and the hexose monophosphate pathways. The authors concluded that plant is effective against antibiotic-resistant strains of pathogens.

The zone of inhibition by extracts of Tetraptera tetrapleura pod were in the order; aqueous $<$ acetone $<$ ethanol $<$ Ampiclox for all the isolates. The variation among the extracts could be due to changes in solvent properties used for the study. Similar trend have been reported by Epidi, et al. [1,2], Kigigha, et al. [9]. Authors have reported that polarity of solvent affect the zone of inhibition among plants that have antibacterial properties $[1,2,9]$.

The variation in the mean values of the different isolates could be due to differences in metabolism, physiology, nutrition and biochemistry of the isolates $[1,2,30]$. Environmental conditions such as temperature and $\mathrm{pH}$ of the extracts may also account for significant variation among the isolates [3].

The Tetrapleura tetraptera is potent against E. coli, Staphylococcus aureus, Pseudomonas and Proteus species. This is an indication that it can be used as broad spectrum antibiotic. Furthermore, based on Table 1 , the values of known antibiotics were higher than the values reported on the various extracts of Tetrapleura tetraptera. The variation could be due to the specificity of the known antibiotics, as well as the concentration. Again, most of the known antibiotics tested in this study have been previously reported by authors to be potent to both gram positive and gram negative organisms by authors $[1,2,9,30]$.

\section{Conclusion}

Medicinal plants are plants whose different parts such as fruit, leaves, stem, back, flower, and juice have therapeutic purposes or precursor's substance for the synthesis of useful drugs. This study focused on the antibacterial efficacy of aqueous, acetone and ethanolic extracts of Tetrapleura tetraptera pod against E. coli, Staphylococcus aureus and Pseudomonas and Proteus species. The study found that the pod of Tetrapleura tetraptera pod has antibacterial activities. Furthermore, the efficacy of the various solvent was in the order: ethanol> acetone >aqueous. The positive results suggest that the Tetrapleura tetraptera pod can be used as a broad spectrum antibiotic. Therefore, there is need for studies to focus on the isolating the bioactive constituents of the plant that makes it possess antibacterial potentials.

\section{References}

1. Epidi JO, Izah SC, Ohimain EI (2016a) Antibacterial and synergistic efficacy of extracts of Alstonia boonei tissues. British J Applied Sci 1: 21-26.

2. Epidi JO, Izah SC, Ohimain EI, Epidi TT (2016b) Antibacterial and synergistic potency of tissues of Vitex grandifolia. Biotechnol Res 2: 69-76.

3. Izah SC (2018) Some determinant factors of antimicrobial susceptibility pattern of plant extracts. Res Rev Insights 2: 1-4

4. Izah, SC, Etim, NG, Ilerhunmwuwa, IA, Ibibo, TD, Udumo JJ (2019) Activities of Express Extracts of Costus afer Ker-Gawl. [Family COSTACEAE] Against Selected Bacterial Isolates. Int J Pharma Phytopharma Res 9: 39-44.

5. Izah SC, Etim NG, Ilerhunmwuwa IA, Silas G (2019) Evaluation of crude and ethanolic extracts of Capsicum frutescens var. minima fruit against some common bacterial pathogens. Int J Complementary and Alternative Med 12:105-108.

6. Izah SC, Zige DV, Alagoa KJ, Uhunmwangho EJ, Iyamu AO (2018) Antibacterial Efficacy of Aqueous Extract of Myristica fragrans (Common Nutmeg). EC Pharmacol Toxicol 6: 291-295.
7. Izah SC, Uhunmwangho EJ, Dunga KE, Kigigha LT (2018) Synergy of methanolic leave and stem-back extract of Anacardium occidentale 1 (cashew) against some enteric and superficial bacteria pathogens. MOJ Toxicol 4: 209-211.

8. Izah SC, Uhunmwangho EJ, Dunga KE (2018) Studies on the synergistic effectiveness of methanolic extract of leaves and roots of Carica papaya L (papaya) against some bacteria pathogens. Int J Complementary and Alternative Med 11:375-378.

9. Kigigha LT, Izah SC, Ehizibue M (2015) Activities of Aframomum melegueta Seed Against Escherichia coli, S. aureus and Bacillus species. Point Journal of Botany and Microbiology Research 1: 23-29.

10. Kigigha LT, Selekere RE, Izah SC (2018) Antibacterial and synergistic efficacy of acetone extracts of Garcinia kola (Bitter kola) and Buchholzia coriacea (Wonderful kola). J of Basic Pharmacol \& Toxicol 2: 13-17.

11. Kigigha LT, Izah SC, Uhunmwangho EJ (2018) Assessment of hot water and ethanolic leaf extracts of Cymbopogon citratus Stapf (Lemon grass) against selected bacteria pathogens. Annals of Microbiology and Infectious Dis 1: 1- 5 .

12. Okwute SK, Olajide OO, Etuk-Udo G, Orishadipe AT (2016). Phytochemical Screening, In-vitro Antimicrobial Activity and Antioxidant Characteristics of Tetrapleura tetraptera Extracts. Euro J Med Plants 17: 1-10

13. Enema OJ, Adesina SK, Umoh UF, Eseyin OA (2019) Gas chromatography-mass spectroscopy (GC-MS) studies of fixed oil of leaf of Tetrapleura tetraptera Taub. (Mimosaceae). J Pharmacog Phytochem 8: 1237-1241.

14. Enema OJ, Umoh UF, Thomas PS, Adesina SK, Eseyin OA (2019). Phytochemical and antioxidants studies of leaf of Tetrapleura tetraptera (Schum\& Thon) Taubert (Mimosaceae). British J Pharma Med Res 4: 1865-1875.

15. Ojewole JAO, Adewunmi CO (2004) Anti-inflammatory and hypoglycaemic effects of Tetrapleura tetraptera (Taub) [fabaceae] fruit aqueous extract in rats. J Ethnopharma 95: 177-182.

16. Oniya MO, Idowu OF (2013) Evaluation of the toxicity of the oil extract of Tetrapleura tetraptera on tadpoles [Amphibia: Anura]. FUTA J Res Sci 1: 172-176.

17. Seiyaboh EI, Odubo TC, Izah SC (2020) Larvicidal Activity of Tetrapleura tetraptera (Schum and Thonn) Taubert (Mimosaceae) extracts against Anopheles gambiae. Int $J$ Advanced Res Microbiol Immunol 2: 20-25.

18. Adesina SK, Iwalewa EO, Johnny II (2016) Tetrapleura tetrapteraTaubEthnopharmacology, chemistry and nutritional values- a review. British J Pharma Res 12: $1-22$.

19. Aderibigbe AO, Iwalewa EO, Adesina SK, Agboola OI (2010) Studies of behavioura and neural mechanism of aridanin isolated from Tetrapleura tetraptera fruit in mice. Int J Pharmacol 6: 480-486.

20. Aladesanmi AJ (2007). Tetrapleura tetraptera: Molluscicdal activity and chemical constituents. African J Traditional, Complementary and Alternative Med 4: 23-36.

21. Ebana RUB, Edet UO, Ekanemesang UM, Ikon GM, Etok CA, Edet AP (2016) Antimicrobial Activity, Phytochemical Screening and Nutrient Analysis of Tetrapleura tetraptera and Piper guineense. Asian J Med Health 1: 1-8

22. Achi OK (2006) Composition and Antibacterial Activities of Tetrapleura tetraptera Taub. Pod Extracts. Res J Microbiol 1: 416-422.

23. Cheesbrough M (2004) District Laboratory Practice in Tropical Countries. Low price Edition part 2. Cambridge press, England.

24. Benson HJ (2002) Microbiological Applications: Laboratory Manual in General Microbiology. complete version, 5th edition. McGaraw-Hill, New York.

25. Lino A, Deogracious O (2006) The invitro antibacterial activity of Annonnasenegalensis, Sacuridecaelongipendiculata and Steganotaemaaraliacea. Uganda medicinal plants. $J$ African Health Sci 6: 31-35.

26. Doherty VF, Olaniran OO, Kanife UC (2010) Antimicrobial activities of AframomumMelegueta (Alligator pepper). Int J Biol 2: 126-131.

27. Agu GC, Thomas BT (2012) Antibacterial Activities of Ethanol and Aqueous Extracts of Five Nigerian Medicinal Plants on Some Wound Pathogens. Nature and Science 10: $78-84$.

28. Izah SC, Aseibai ER (2018) Antibacterial and Synergistic activities of methanolic leaf extract of Lemon grass (Cymbopogon citratus) and rhizome of Ginger (Zingiber officinale) against Escherichia coli, Staphylococcus aureus and Bacillus species. ACTA Microbiol 1: 26-30. 
29. Lin L, Agyemang K, Abdel-Samie MA-S, Cui H (2019) Antibacterial mechanism of Tetrapleura tetraptera extract against Escherichia coli and Staphylococcus aureus and its application in pork. J Food Safety 39: e12693.
30. Kigigha LT, Biye SE, Izah SC (2016) Phytochemical and antibacterial activities ofMusangacecropioides tissues against Escherichia coli, Pseudomonas aeruginosa Staphylococcus aureus, Proteus and Bacillus species. Int J Applied Res Technol 5: 100-107.

Copyright: (C2021 Enaregha EB. This is an open-access article distributed under the terms of the Creative Commons Attribution License, which permits unrestricted use, distribution, and reproduction in any medium, provided the original author and source are credited. 